This item was submitted to Loughborough's Research Repository by the author.

Items in Figshare are protected by copyright, with all rights reserved, unless otherwise indicated.

\title{
Feasibility of zero carbon homes in England by 2016: a house builder's perspective
}

PLEASE CITE THE PUBLISHED VERSION

VERSION

AM (Accepted Manuscript)

LICENCE

CC BY-NC-ND 4.0

\section{REPOSITORY RECORD}

Osmani, Mohamed, and Alistair O'Reilly. 2019. "Feasibility of Zero Carbon Homes in England by 2016: A House Builder's Perspective”. figshare. https://hdl.handle.net/2134/4797. 
This item was submitted to Loughborough's Institutional Repository (https://dspace.lboro.ac.uk/) by the author and is made available under the following Creative Commons Licence conditions.

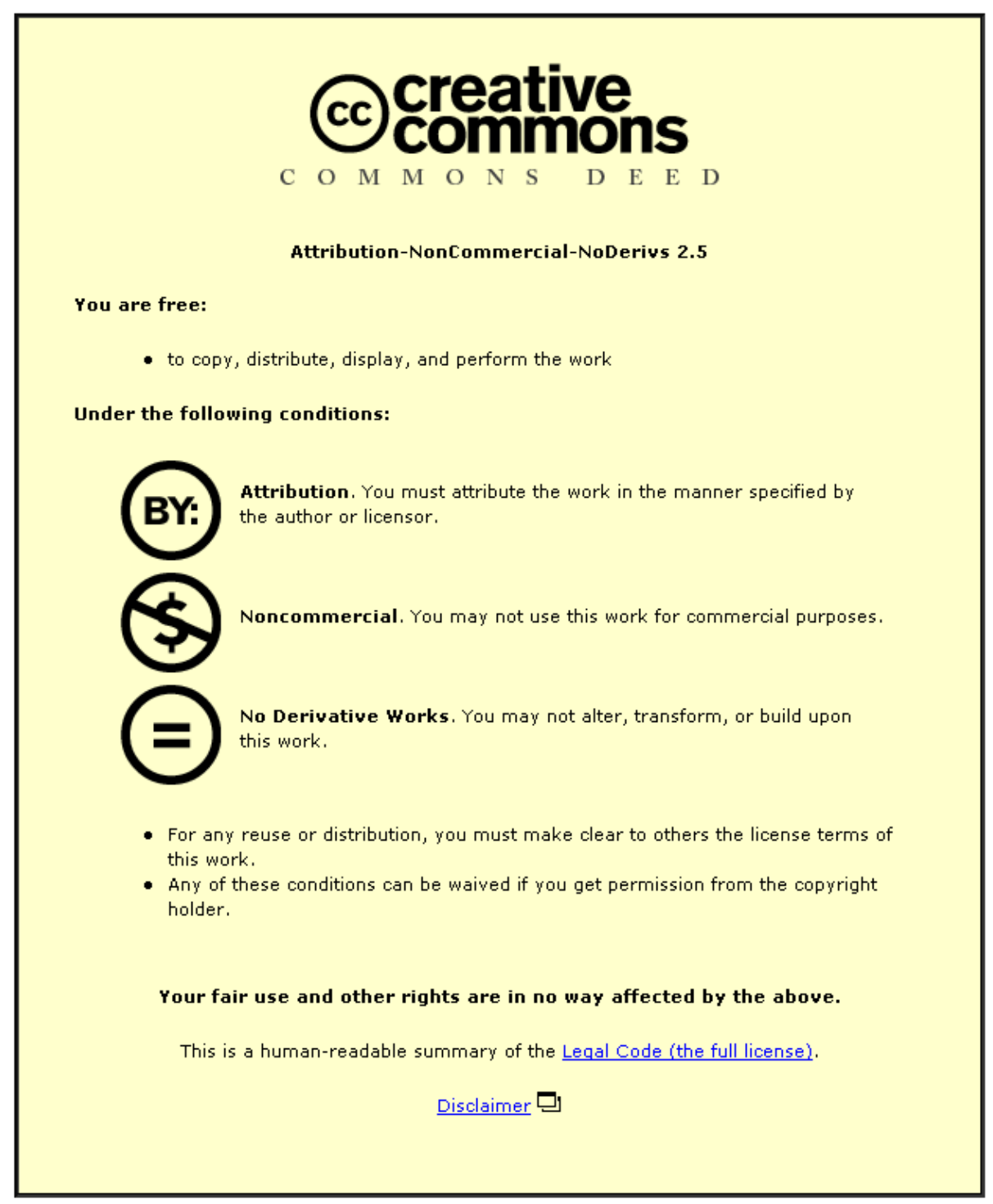

For the full text of this licence, please go to: http://creativecommons.org/licenses/by-nc-nd/2.5/ 
Osmani, M*. and O'Reilly, A., "Feasibility of zero carbon homes in England by 2016: A house builder's perspective", Building and Environment, 44 (9), September 2009, pp 1917-1924.

* Corresponding author (Email: m.osmani@lboro.ac.uk)

\title{
FEASIBILITY OF ZERO CARBON HOMES IN ENGLAND BY 2016: A HOUSE BUILDER'S PERSPECTIVE
}

\author{
Mohamed Osmani* \\ Department of Civil and Building Engineering, Loughborough University, UK \\ Tel: $+44(0) 1509843164$ \\ Fax: + $44(0) 1509223981$ \\ Email: m.osmani@lboro.ac.uk \\ Alistair O’Reilly \\ Laing O'Rourke Site Offices, Larch Villa, Off Laneham Road, \\ Retford DN22 0AF, UK \\ Tel: + 44 (0) 1777880332 \\ Fax: + $44(0) 1777249172$ \\ Email: AO'Reilly@laingorourke.com
}

\begin{abstract}
The UK government set itself a 60 per cent reduction of carbon dioxide emissions target on 2000 levels by 2050 . This commitment will require carbon reductions to be made by all industries including the housing sector which presently accounts for 27 per cent of carbon dioxide emissions. The house building industry is the subject of numerous government policies and legislation, but none are as demanding as the Code of Sustainable Homes, which set a 'world-beating' target for all new homes to be zero carbon by 2016. This paper sets out to investigate the feasibility of building zero carbon homes in England by 2016 from a house builder's perspective. A comprehensive opinion of the feasibility of zero carbon homes is gathered through a questionnaire survey and in-depth semi-structured interviews with the major UK housing developers. The research found that there are currently numerous legislative, cultural, financial and technical barriers facing house builders to deliver zero carbon homes in England by 2016..The surveyed house builders concurred that these challenges are not insurmountable provided that a swift, all-embracing and above all realistic strategy is adopted and implemented across the supply chain.
\end{abstract}

Keywords: Zero Carbon Homes, Drivers, Barriers, Housing Practices, House builders, England. 


\section{Introduction}

Climate change has established itself as a major issue, which requires an urgent and coordinated global response. To help tackle global warming, the UK is putting itself on a path to cut its carbon dioxide emissions by some 60 per cent on 2000 level by 2050, with real progress by 2020 [1]. This was superseded by a government announcement in October 2008 for a more ambitious target committing the UK to cut greenhouse gas emissions by $80 \%$ by the middle of the century [2]. This commitment will require carbon reductions to be made by all industries including the housing sector [3]. Carbon dioxide emissions from the housing sector have risen by more than five per cent since 1997 and account for 27 per cent of the UK's carbon footprint [1]. The government has consequently highlighted the house building industry as a key sector where carbon reductions can be made. The UK house building industry has been the subject of numerous government reports and initiatives in recent years, such as the previous Deputy of Prime Minster Office’s £60K home programme, which was launched in 2004 and targeted production rates and the affordability of new build homes [4]. Indeed, the programme has challenged the house-building industry to look at how it can make construction methods more efficient by designing and building to high standards for a housing unit construction cost of $£ 60,000$. As a result, house builders are under increasing pressure to provide sustainable as well as affordable housing whilst increasing production rates to 240,000 units per year by 2016 [5]. In December 2006, the government published the Code for Sustainable Homes (CSH) as a pathway to achieving zero carbon homes in England [6]. The CSH sets ambitious targets for the house building industry, for which the commercial benefits and costs are still unknown. The aim of this paper is to examine the feasibility of zero carbon homes in England by 2016 from house builders’ perspectives.

\section{Low carbon housing drivers}

Despite the current economic and political environment, multiple drivers exist for the development of low carbon housing in the UK. These are broadly clustered under three categories: business, cultural, and legislative drivers, which are examined below.

\subsection{Business drivers}

With a substantial number of house builders being amongst the largest companies in the UK, there is a growing culture of corporate social responsibility (CSR) within the industry. The importance attached to CSR was strongly illustrated in the WWF (2007) report, entitled 'Building a Sustainable Future' [7], where a survey of 20 of the UK largest housing developers revealed that 70\% report publicly on their approach to sustainability and $65 \%$ have a corporate sustainability policy in place. Consequently, CSR has the potential to be a powerful driver for zero carbon homes, as companies strive to improve their environmental performance. Furthermore, Carter 
(2006) [8] stated that in exceeding minimum sustainability standards house builders can benefit from enhanced brand recognition and reputation. Similarly, the WWF (2005) report, 'Investing in Sustainability’ [9], also indicated that achieving high standards of environmental and social performance can be used to a developer’s advantage to attract customers and high calibre employees. However, the construction supply chain could have a more profound impact on the zero carbon agenda. Indeed, a study by Keeping and Shires (2004) [10] found that the supply chain is more motivated to develop green products and practices due to their marketing objectives and the market differentiation they can benefit from.

\subsection{Cultural drivers}

Whilst customer demand for low-carbon housing is currently limited, it is recognised as a growing market and area of interest [8]; [11]. A study carried out by Sponge Sustainability Network (2007) [12] found that there is a growing desire amongst the UK public to adopt more sustainable lifestyles. The growth in customer demand is likely to encourage house builders to voluntarily integrate sustainable features into future developments. It is suggested that this growing low carbon culture could be built upon by government initiatives, either through the provision of fiscal incentives as recommended by Dobson (2007) [13] or the integration of sustainability factors in property valuations as detailed by Lutzendorf and Lorenz (2007) [14]. Favourable planning policies, such as Planning Policy Statement 1 -PPS1[15], and existing government policies, such as the Energy White Paper [1], which are aimed at promoting sustainability in the built environment, are likely to further enhance the integration of such features and the promotion of a low carbon culture. Moreover, these policies pave the way for new legislation, which stakeholders in the building industry are shown to respond best to [16]; [17]; [18].

\subsection{Legislative drivers}

The prospect of future legislation itself should prove to be a major driver in achieving zero carbon homes by 2016 [19]. It is anticipated that the CSH, a voluntary scheme at present, becoming legislation is likely to be the most influential driver for house builders to build zero carbon homes and that those who adopt a pro-active attitude will gain extensive and practical knowledge of low carbon house building, from which they will benefit financially by being capable of meeting the enhanced building requirements more cost effectively [8]. The potential introduction of the CSH as legislation, along with the implementation of Energy Performance Certificates in line with the Energy Performance in Buildings Directive, has been highlighted in a study by Vorsatz et al. (2007) [20], as being highly successful in terms of reductions in CO2 emissions and cost effectiveness, to the point that these measures could be major drivers for zero carbon housing.

\section{Low carbon housing barriers}

Numerous barriers to low carbon homes in England stand in the way of designing and building energy 
efficient housing developments. The principal barriers encountered appear to be design and technical, cultural, legislative, and financial barriers.

- Technical and design barriers are one of the main considerations when looking at the feasibility of zero carbon homes in the UK, as a step change in the housing construction process [6]. One of the primary issues with the construction of zero carbon homes is the integration of renewable technologies into small scale developments, as it is widely perceived that such technologies are currently unreliable [21] and are believed to be installed to the detriment of profit, outside space and aesthetics [22]. A further design barrier revolves around the fact that volume house builders in the UK tend to use a range of standard house sets across their developments to help reduce costs and defects and as a consequence, they are reluctant to adopt policies which require excessive design changes [21].

- The technical and design barriers listed above are quite closely tied to the cultural barriers opposing the successful construction of zero carbon homes in the UK. Within the UK house building sector, an unwillingness to implement untested or new sustainable materials and products has been recently recorded in a study by Williams and Adair (2007) [21]. This is a result of the traditional attitudes maintained within the house building sector, which restrict the uptake of innovations [23]; [24]. Compounding this unwillingness to stray from tradition is a lack of sustainability requirements by clients as identified in a study by Sponge Sustainability Network (2007) [12] and the widespread perception that there is currently a lack of demand for sustainable properties amongst the general public $[25] ;[21]$.

- The perceived increased costs of achieving high building standards associated with low and zero carbon homes is yet another hurdle restraining house builders from attempting to overcome the existing cultural, design and technical challenges. Several studies revealed that housing developers are reluctant to instigate innovation and achieve high sustainability standards due to the prohibitively received or real elevated costs associated with the implementation of such standards [23] ; [25]. The latter has become more apparent since the introduction of the CSH. Indeed, Williams and Adair (2007) [21] and Cato (2008) [26] concurred that the high cost of certain sustainable measures is a major barrier to low carbon homes when compared to traditional buildings. Moreover, this issue is exacerbated by the uncertainty surrounding the actual cost of achieving the different levels of the CSH. Studies completed to date have shown that the cost of achieving the different levels of the CSH will vary depending on the economies of scale available to each particular house builder and the construction methods employed [27] ; [28]. 
Taking into consideration the lack of cost and financial data associated with the construction of zero carbon homes, coupled with current cultural and technical concerns towards sustainability, it is clear that in light of the current financial climate the government is likely to face several challenges and hurdles in achieving its zero carbon homes objective. Additionally, the current excess of energy efficiency policies, which has been shown to have a slow uptake amongst house builders [29], will create yet another obstacle if it is not followed up with concrete legislation. This is supported by the results of a study by Adeyeye et al. (2007) [16], which showed that building design was not often affected by policies but responded well to legislation. Therefore, there is a call for the UK government to move away from energy conservation policy making towards the production of detailed yet balanced legislation to help create a market for sustainability [30]. As such, house builders would be further driven to address the numerous barriers to the construction of zero carbon homes, which will ultimately become widespread in the UK.

\section{The Code for Sustainable Homes (CSH)}

The CSH is set to be the basis of future sustainable building standards in the UK housing sector. The CSH incorporates nine key sustainability issues into one policy document ranging from water usage to the health and well-being of a house's occupants.

Central to the CSH are the energy efficiency and $\mathrm{CO} 2$ emissions of new homes, whichare embedded in a mandatory section of the $\mathrm{CSH}$ in which minimum standards must be met in order to become accredited.It is interesting to note that the CSH exceeds other international housing standards such as the 'R-2000' in Canada [31] and 'PassivHaus' in Germany[32], as it specifies that any domestic energy required must be generated by renewable sources in order to achieve a level 6 zero carbon home. This surpasses the PassivHaus standard, which sets a maximum energy usage level of $15 \mathrm{kWh} / \mathrm{m}^{2} \mathrm{y}$ for space heating and cooling but does not specify permissible energy sources [32]. As such, when combined with the other categories required in the CSH such waste, water usage and materials, the Code is amongst the most challenging and demanding international housing standards. The CSH uses a star system to rate properties with ' 1 ' star representing a $10 \%$ improvement over Part L of the Building Regulations 2006 and ' 6 ' stars equating to a zero carbon home [6]. This star rating system was deemed more suitable than the previous EcoHomes system of 'Pass' to 'Excellent' [12]. The standards set by the CSH, will be gradually implemented through compulsory changes to the Building Regulations. Consultations are currently ongoing [5], however, the proposals involve incorporating level 3 (25\% improvement over part L) in 2010 and level 4 (44\% improvement) in 2013 before finally moving to zero carbon homes by 2016 . 


\section{Methodology}

The research adopted a threefold methodology, consisting of a desk study, quantitative and qualitative research methods. The quantitative research took the form of postal questionnaire distributed to the major house builders in England. The questionnaire was designed around the findings of the desk study to establish a general house building industry-wide perspective on current low energy housing building practices; and examine the drivers and challenges to design and built zero carbon homes. The survey population was confined to the top 100 house builders in England. The largest house building companies were targeted for this survey because each has considerable and adequate resources in place, which should potentially facilitate the planning, enforcement and implementation of zero carbon strategies in their projects, when compared with smaller housebuilders.

Additionally, most of these organisations have various offices and construction sites across most regions in England. The questionnaire contained four main sections: low carbon housing drivers; current low carbon practice; barriers to zero carbon homes, and the feasibility of zero carbon homes by 2016. The key questions, namely current low carbon practices, and drivers and barriers to zero carbon homes, were designed to be closedended using a scale from ' 1 ' (lowest level) to '5' (highest level). For example, respondents were asked to rate from 1 to 5 a number of barriers to zero carbon homes in England (1: not a barrier; 2: insignificant; 3: minor; 4: significant; and 5: major barrier). Additionally, a space was provided at the end of each section to elaborate on the respondents' rating selection and accommodate additional information.

The findings of the questionnaire survey were augmented via in-depth semi-structured interviews, which provided the qualitative research for the study. The aim of the interviews was to build upon the quantitative data resulting from the questionnaire with a specific focus on the viability of zero carbon homes by2016. In total, eight interviewees, who indicated in the questionnaire responses that they would be willing to partake in further research, were selected. An interview template was issued to the interviewees one week prior to the scheduled dates to allow a certain degree of preparation. Additionally, the use of probes during the interview proceedings based on the literature and questionnaire's results allowed maximum benefit to be obtained from the interviews, as they facilitated a detailed investigation into the challenges and feasibility of zero carbon homes by 2016.

\section{Results}

Results of both the questionnaire survey and interviews gave valuable insights into house builders' current low carbon practices; and challenges facing the house building industry in England to build zero carbon homes by 2016. Of the 100 targeted house builders, 41 completed questionnaires were received, representing a 41 per cent response rate. The respondents' quantitative and qualitative responses to the main themes of the research are discussed below. 


\subsection{Background information}

In terms of geographical location, a breakdown of the returned questionnaires is summarised in Table 1 . There is a relatively even spread of results from around the country. The lack of responses from housebuilders in the South West of England is partially due to the low volume of housing work currently being completed in that region. Conversely, a strong response rate from the housing developers operating in the South East of England, which predominantly have their headquarters in the greater London area, represented half of all responding companies.

Table 1: Geographical spread of house building activities and associated response rates

(Questionnaire responses)

\begin{tabular}{lcc}
\hline $\begin{array}{l}\text { Geographical spread of } \\
\text { activities in England }\end{array}$ & No. of respondents & Response rate \\
\hline South West & 2 & $5 \%$ \\
\hline South East & 11 & $27 \%$ \\
\hline Midlands & 9 & $22 \%$ \\
\hline North West & 7 & $17 \%$ \\
\hline North East & 4 & $10 \%$ \\
\hline National & 8 & $19 \%$ \\
\hline
\end{tabular}

Figure 1 gives insights into the turnover of the surveyed housebuilders. More than $40 \%$ of responding housebuilders have an annual turnover of more than $£ 500$ million, of which $13 \%$ exceed $£ 1$ billion. On the other hand, housebuilders with a turnover of less than $£ 100$ million, represented around the tenth of the surveyed population.

Figure 1: Annual turnover of responding housebuilders

(Questionnaire responses)

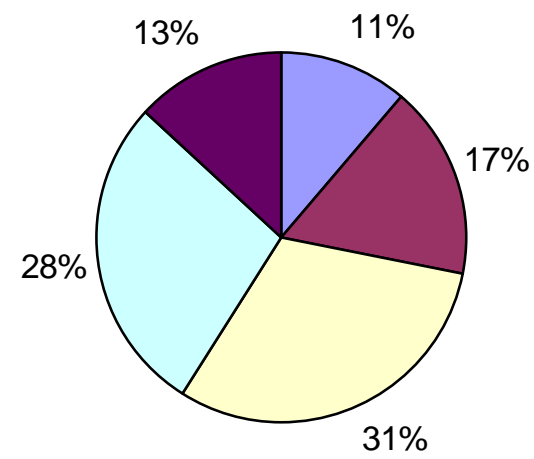

Up to $£ 99.99 m$

$£ 100 m-£ 249.99 m$

$£ 250 \mathrm{~m}-£ 499.99 \mathrm{~m}$

$\square £ 500 \mathrm{~m}-£ 999.99 \mathrm{~m}$

Over $£ 1,000 m$ 
As shown in Table 2, the eight interviewees hold senior management positions in their respective companies.

The annual turnover and geographical spread of activities of the interviewed housebuilders are in line with the trend of the questionnaire institutional responses, which is fairly representative of the overall target population of the study.

Table 2: Interviewees details: individual positions, companies turnover and geographical spread of house building activities (Questionnaire responses)

Interviewer \#
1
2
3
4
5
6
7
8

Managing Director

Position

Company turnover

(£ million)

402

Technical Director

95

1,150

Head of Sustainable Development

210

Product Development Director

677

Technical Director 518

Sustainability Project Manager

3,554

Managing Director

275

Geographical spread of
house building activities
South-West
South-West
National
Midlands
National
South- East
National
North-West

\subsection{Current low carbon house building practices}

Contrary to expectations, sustainability was high on the agenda of most of the respondents to the questionnaire.

Table 3 shows the initial responses, with $51 \%$ of respondents commenting that they have a sustainability policy in place and a further $29 \%$ stating that they were in the process of creating one. Similarly, $56 \%$ of the surveyed house builders reported that they have a Corporate Social Responsibility (CSR) policy or were in the process of developing one. However, only 7 per cent of house builders hold ISO 14001 accreditation , which appears rather contradictory.

Table 3: Existing sustainability policies and standards (Questionnaire responses)

\begin{tabular}{llll}
\hline & Yes & No & In the Process \\
\hline Sustainability policy in place & $51 \%$ & $20 \%$ & $29 \%$ \\
\hline Corporate Social Responsibility policy in place & $41 \%$ & $44 \%$ & $15 \%$ \\
\hline ISO 14001 accreditation & $7 \%$ & $83 \%$ & $10 \%$ \\
\hline
\end{tabular}

When asked to what extent they implement low carbon technologies and practices in their current projects, house builders argued that in addition to the mandatory requirements of using high efficient condensing boilers, they have been adopting a consistent approach in implementing thermally efficient and low air permeability building fabric, as shown in Table 4. The latter is in sharp contrast with the frequency of using high efficiency glazing, which is commonly or always used by only $5 \%$ of respondents. Equally, just $12 \%$ said that they always integrate renewable energy features in their housing projects. 
Table 4: Current implementation of low carbon technologies and practices (Questionnaire responses)

\begin{tabular}{llllll}
\hline & Never Used & Rarely used & $\begin{array}{l}\text { Occasionally } \\
\text { Used }\end{array}$ & $\begin{array}{l}\text { Commonly } \\
\text { Used }\end{array}$ & $\begin{array}{l}\text { Always } \\
\text { Used }\end{array}$ \\
\hline Renewable Energy Features & $24 \%$ & $7 \%$ & $39 \%$ & $17 \%$ & $12 \%$ \\
\hline $\begin{array}{l}\text { High Efficiency Condensing } \\
\text { Boilers }\end{array}$ & $2 \%$ & $2 \%$ & $7 \%$ & $27 \%$ & $61 \%$ \\
\hline $\begin{array}{l}\text { Triple Glazing } \\
\text { Highly Thermally Efficient }\end{array}$ & $0 \%$ & $29 \%$ & $12 \%$ & $0 \%$ & $5 \%$ \\
\hline Building Fabric & $54 \%$ & $5 \%$ & $20 \%$ & $39 \%$ & $37 \%$ \\
\hline \begin{tabular}{l} 
Low Air Permeability \\
\hline
\end{tabular} & $2 \%$ & $0 \%$ & $29 \%$ & $32 \%$ & $37 \%$ \\
\hline
\end{tabular}

A commitment to low carbon building was reiterated as a strategic objective by all of the interviewees, commenting that they have integrated renewable or sustainable technologies into their projects to a greater or lesser degree depending on the client’s brief. As such, five interviewees stated that they had previously been accredited with EcoHomes 'Excellent' rating on some of their developments. The remaining three housebuilders commented that although they had not sought EcoHomes accreditation on previous projects, they maintained basic sustainable standards and integrated additional low carbon technologies whenever feasible.

\subsection{Drivers for Zero Carbon Homes}

Respondents were asked to rate the most influencing drivers to zero carbon housing developments using a scale of 1-5. As anticipated, Figure 2 shows that legislative drivers have the highest impact on house builders' current work practices (mean value of 3.89). However, and contrary to expectation, cultural drivers was accorded the second highest mean impact rating (3.58), followed closely by business drivers (3.48), then financial drivers

Figure 2: Thematic drivers for zero carbon homes in England (Questionnaire responses)

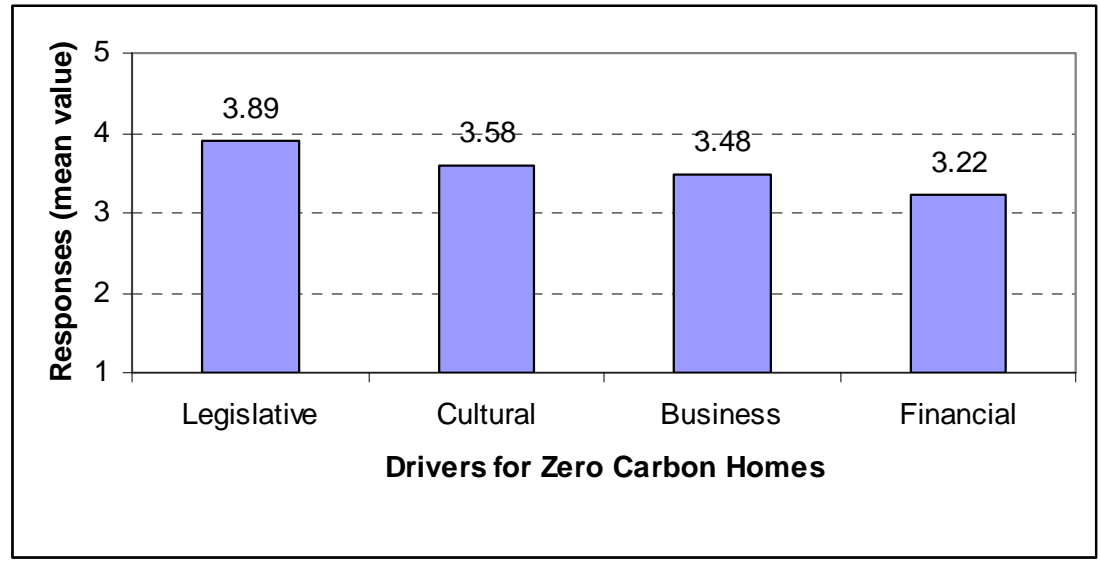

1: Not a driver; 2: Insignificant driver; 3: Minor driver; 4: Significant driver; 5: Major driver 
Respondents were asked to give further details by rating the most influencing key driving forces related to each category: legislative, cultural, business and financial drivers; their answers are shown in Table 5.

\begin{tabular}{|c|c|c|c|c|c|c|}
\hline & $\begin{array}{l}\text { Not a } \\
\text { driver }\end{array}$ & $\begin{array}{l}\text { Insignificant } \\
\text { driver }\end{array}$ & $\begin{array}{l}\text { Minor } \\
\text { driver }\end{array}$ & $\begin{array}{l}\text { Significant } \\
\text { driver }\end{array}$ & $\begin{array}{l}\text { Major } \\
\text { driver }\end{array}$ & $\begin{array}{l}\text { Mean } \\
\text { Value }\end{array}$ \\
\hline \multicolumn{7}{|l|}{ LEGISLATIVE } \\
\hline Environmental legislation & $0 \%$ & $2 \%$ & $2 \%$ & $22 \%$ & $73 \%$ & 4.66 \\
\hline Government policies & $5 \%$ & $7 \%$ & $10 \%$ & $29 \%$ & $49 \%$ & 4.10 \\
\hline Planning policies & $2 \%$ & $5 \%$ & $22 \%$ & $41 \%$ & $29 \%$ & 3.90 \\
\hline Home Information Packs (HIPS) & $12 \%$ & $17 \%$ & $41 \%$ & $27 \%$ & $2 \%$ & 2.90 \\
\hline \multicolumn{7}{|l|}{ CULTURAL } \\
\hline $\begin{array}{l}\text { Innovation from within Supply } \\
\text { Chains }\end{array}$ & $0 \%$ & $10 \%$ & $5 \%$ & $39 \%$ & $46 \%$ & 4.22 \\
\hline $\begin{array}{l}\text { Corporate Social Responsibility } \\
\text { (CSR) }\end{array}$ & $5 \%$ & $7 \%$ & $29 \%$ & $49 \%$ & $10 \%$ & 3.51 \\
\hline Partnerships with Local Councils & $17 \%$ & $17 \%$ & $29 \%$ & $22 \%$ & $15 \%$ & 3.00 \\
\hline \multicolumn{7}{|l|}{ BUSINESS } \\
\hline $\begin{array}{l}\text { Business Risk of Future } \\
\text { Legislation }\end{array}$ & $2 \%$ & $5 \%$ & $20 \%$ & $32 \%$ & $41 \%$ & 4.05 \\
\hline Marketing Benefits & $2 \%$ & $10 \%$ & $20 \%$ & $46 \%$ & $22 \%$ & 3.76 \\
\hline Customer Demand & $5 \%$ & $10 \%$ & $27 \%$ & $41 \%$ & $17 \%$ & 3.56 \\
\hline Ecotown Opportunities & $27 \%$ & $17 \%$ & $37 \%$ & $12 \%$ & $7 \%$ & 2.56 \\
\hline \multicolumn{7}{|l|}{ FINANCIAL } \\
\hline Potential Sales Price Premiums & $15 \%$ & $5 \%$ & $24 \%$ & $34 \%$ & $22 \%$ & 3.44 \\
\hline Fiscal Incentives & $12 \%$ & $0 \%$ & $34 \%$ & $41 \%$ & $12 \%$ & 3.41 \\
\hline Government Grants & $12 \%$ & $12 \%$ & $27 \%$ & $32 \%$ & $17 \%$ & 3.29 \\
\hline $\begin{array}{l}\text { Access to Socially Responsible } \\
\text { Investment Funds }\end{array}$ & $20 \%$ & $15 \%$ & $41 \%$ & $22 \%$ & $2 \%$ & 2.78 \\
\hline
\end{tabular}

- $\quad$ Key legislative drivers: The effect of 'government policies', such as the Energy White Paper [1], on building practice was highlighted by $88 \%$ of respondents as being significant or major drivers. This was, however, surpassed by the importance of ‘environmental legislation', such as compliance with Part L of the Building Regulations [17], as a driver for zero carbon homes, with 95\% of respondents said that the latter was a significant or major driver resulting in a mean score of 4.66. Similar results were achieved in the interviews, where the overall consensus was that "making zero carbon standards mandatory would be the most effective way of driving the industry to build zero carbon homes”. 
- $\quad$ Key cultural Drivers: 'innovation within the supply chain' was rated as a significant or major driver by $85 \%$ of the surveyed respondents. However, in the interviews a collective contrasting opinion emerged shifting the discussion from 'drivers' to 'barriers'. Indeed, the majority of respondents stated that the supply chain could be a major driver if new technologies and products will be developed, however, "the lack of innovation within the supply chain is a major barrier to achieving the CSH". This was mainly related to the inability of the manufacturing side of the supply chain to gradually invest in new technologies to develop innovative products and systems to facilitate compliance with the CSH. It is interesting to note that the results of cultural drivers from the questionnaire survey 'metamorphosed' into technological drivers during the interview proceedings.

- Key business drivers: The questionnaire results revealed that 'business risk of future legislation' emerged as the strongest of business drivers with a mean value of 4.05; followed by 'marketing benefits' (3.76). Surprisingly, customer demand was relatively rated as being a lesser driver for zero carbon homes (3.56). Responses of the interviewees reinforced the importance of business risks associated with legislative compliance by recognising that "the industry will respond best to legislation”. In contrast to literature review findings and to some extent the survey's current low carbon practices' results (Table 3), only 10\% of respondents rated CSR as a major driver. This would suggest that sustainability and CSR policies are strategically used as marketing 'badges' rather than being holistically embedded in projects’ implementation and delivery strategies.

- Key financial drivers: The possibility of achieving sales premiums, and receiving fiscal incentives and government grants received mean scores of 3.44, 3.41 and 3.29 respectively. These findings were clarified during the interviews when it was stated that “grants and incentives aren’t as relevant, as they can’t be implemented easily across the board”. Furthermore, it was found that the interviewees do not believe that there is a potential sales premium beyond the additional cost associated with building zero carbon homes. One of the eight interviewees did, however, state that he had experienced premiums equivalent to the additional cost involved. He added that this was "a significant driver when considered in conjunction with the marketing benefits achieved".

\subsection{Barriers to Zero Carbon Homes}

The questionnaire responses relating to the thematic barriers that hinder the construction of zero carbon homes have been presented in Figure 3. 
Figure 3: Thematic barriers to zero carbon homes in England

(Questionnaire responses)

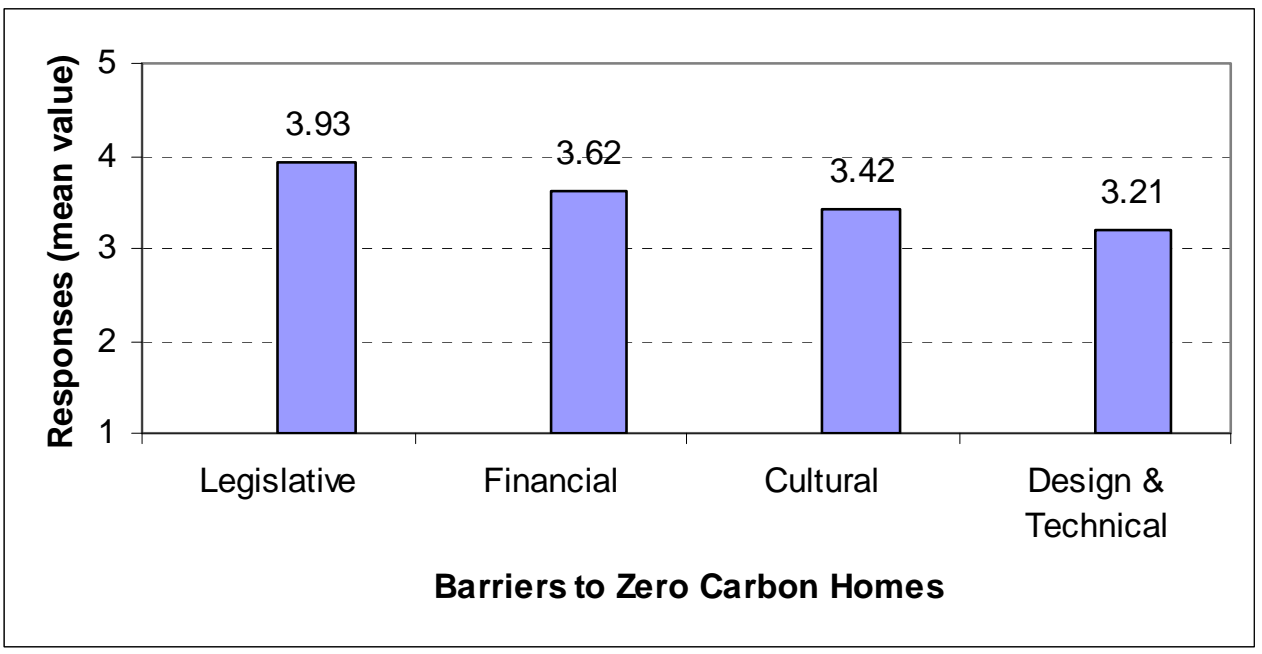

1. Not a barrier

2. Insignificant barrier

3. Minor barrier

4. Significant barrier

5. Major barrier

Complying with legislative requirements was rated as the highest mean importance (3.93), similar to the previous section on drivers. However, informants reported that financial rather than cultural barriers were the second most significant hurdle to zero carbon home building.

Respondents were asked to give further details by rating the most influencing key barriers related to each category: legislative, financial, cultural, and design and technical barriers; their responses are shown in Table 6 .

- $\quad$ Key Legislative barriers: It was found that $73 \%$ of respondents to the survey believed that the definition of zero carbon homes is a significant legislative barrier, as it is ambiguous and needs more clarity in terms of requirements and expected outcomes. The interviewees explained that "uncertainty surrounding issues such as the provision of onsite renewable energy” were negatively impacting on their commitment to the CSH. Interviewees were asked to comment on the possibility of the CSH becoming a legislative requirement in the future. Interestingly, two house builders argued that if the latter will not be implemented in a consistent manner, they would prefer not to build zero carbon homes, and as a consequence are willing to absorb the costs associated with not complying with the 'new' legislation. Additionally, 68\% of respondents opined that "there are too many government policies associated with energy conservation in buildings”. This suggests that house builders would like to see clearly defined guidelines to be merged into one 'pull through' document to replace the existing 
bulk of policies. This was supported by the interviewees who stated that "the current 'fragmented attack' on the zero carbon issue needs to be corrected through the creation of comprehensive and structured legislation”.

Table 6: Key barriers to zero carbon homes in England (Questionnaire responses)

\begin{tabular}{|c|c|c|c|c|c|c|}
\hline & $\begin{array}{l}\text { Not a } \\
\text { Barrier }\end{array}$ & $\begin{array}{l}\text { Insignificant } \\
\text { Barrier }\end{array}$ & $\begin{array}{l}\text { Minor } \\
\text { Barrier }\end{array}$ & $\begin{array}{l}\text { Significant } \\
\text { Barrier }\end{array}$ & $\begin{array}{l}\text { Major } \\
\text { Barrier }\end{array}$ & $\begin{array}{l}\text { Mean } \\
\text { Value } \\
\end{array}$ \\
\hline \multicolumn{7}{|l|}{ LEGISLATIVE } \\
\hline $\begin{array}{l}\text { Unclear definition of zero } \\
\text { carbon }\end{array}$ & $2 \%$ & $10 \%$ & $15 \%$ & $32 \%$ & $41 \%$ & 4.00 \\
\hline $\begin{array}{l}\text { Excess of Government } \\
\text { policies }\end{array}$ & $5 \%$ & $2 \%$ & $24 \%$ & $29 \%$ & $39 \%$ & 3.95 \\
\hline $\begin{array}{l}\text { Lack of understanding of } \\
\text { requirements }\end{array}$ & $7 \%$ & $5 \%$ & $24 \%$ & $24 \%$ & $39 \%$ & 3.83 \\
\hline \multicolumn{7}{|l|}{ FINANCIAL } \\
\hline Lack of cost data & $0 \%$ & $7 \%$ & $15 \%$ & $51 \%$ & $27 \%$ & 3.98 \\
\hline No financial incentives & $0 \%$ & $17 \%$ & $17 \%$ & $24 \%$ & $41 \%$ & 3.90 \\
\hline Lack of sales data & $2 \%$ & $12 \%$ & $15 \%$ & $44 \%$ & $27 \%$ & 3.80 \\
\hline \multicolumn{7}{|l|}{ CULTURAL } \\
\hline $\begin{array}{l}\text { Current practices are built a } \\
\text { current Regulations }\end{array}$ & round & $7 \%$ & $37 \%$ & $44 \%$ & $7 \%$ & 3.41 \\
\hline $\begin{array}{l}\text { Lack of confidence in emer } \\
\text { green technologies }\end{array}$ & ging & $5 \%$ & $17 \%$ & & $32 \%$ & 3.98 \\
\hline $\begin{array}{l}\text { Lack of demand from } \\
\text { customers }\end{array}$ & $10 \%$ & $12 \%$ & $32 \%$ & $24 \%$ & $22 \%$ & 3.37 \\
\hline $\begin{array}{l}\text { Management is not pro- } \\
\text { active }\end{array}$ & $15 \%$ & $22 \%$ & $29 \%$ & $24 \%$ & $10 \%$ & 2.92 \\
\hline \multicolumn{7}{|l|}{ DESIGN } \\
\hline $\begin{array}{l}\text { Reluctance to vary from } \\
\text { traditional design }\end{array}$ & $7 \%$ & $17 \%$ & $27 \%$ & $34 \%$ & $15 \%$ & 3.32 \\
\hline $\begin{array}{l}\text { Reduced amount of } \\
\text { design data }\end{array}$ & $10 \%$ & $10 \%$ & $39 \%$ & $29 \%$ & $12 \%$ & 3.24 \\
\hline $\begin{array}{l}\text { Aesthetics of renewable } \\
\text { technologies }\end{array}$ & $10 \%$ & $24 \%$ & $17 \%$ & $39 \%$ & $10 \%$ & 3.15 \\
\hline
\end{tabular}

- Key Financial barriers: the lack of data relating to the cost of zero carbon homes and a shortage of financial incentives were recognised by $78 \%$ and $71 \%$ of the survey participants respectively as being significant or major barriers. The interviewees saw the additional costs associated with building zero carbon homes as being a major financial impediment. A reoccurring comment was the fact that nobody knows exactly how much it is going to cost to build in accordance with the CSH. One interviewee did shed some light on the issue by stating that "the costs of implementing the Code will be different for 
every house builder, hence companies cannot rely on government or industry estimates”. Additionally, interviewees commented that the cost of zero carbon homes will have to come off land prices. This would indicate that currently house builders do not have a clear signposting with regard to the net financial cost and overall profitability of building zero carbon homes in England.

- $\quad$ Key Cultural barriers: Respondents raised serious concerns relating to the lack of the house building industry confidence in renewable technologies on one hand, and customer demand for zero carbon homes on the other. As such, $46 \%$ of questionnaire respondents and all interviewees argued that the lack of widespread customer demand for zero carbon housing is a significant barrier. One interviewee went further by pointing out stated that "there is a substantial amount of education that needs to happen for the general public to appreciate the benefits of zero carbon homes”. However, informants acknowledged that an increase in customer demand had been recognised recently, which should gradually improve due to factors such as the introduction of Energy Performance Certificates, Stamp Duty exemption and increasing energy prices. A lack of confidence amongst house builders in emerging green technologies was a recurring and persistent problematic issue in the study with 76\% commenting that it is a significant to major barrier. This was echoed during the interviews with all interviewees expressing concern about the reliability of emerging technologies and associated pay-back periods. Several interviewees went further by stating that the National House-Building Council (NHBC) also has similar concerns. This was further explained by one interviewee, who is also a nonexecutive member of an NHBC services board, who confirmed that the NHBC is "concerned about micro-renewables being bolted on following several instances where damage has occurred after their installation”. This is potentially a major concern that needs addressing sooner rather that later as on-site renewables are a requirement under the CSH.

- $\quad$ Design and technical barriers: if compared with the previously discussed challenges, the questionnaire respondents rated lightly the impact of design and technical barriers on zero carbon home design and construction. This might suggest that the industry believes zero carbon homes are technically feasible and that legislative, financial and cultural issues will be more substantial and difficult to overcome. This was in line the interviews' results where there was an agreement among all participants that "the house building industry will achieve the targets set by the government as soon as there is well rounded legislation in place”. At that stage, house builders will have to overcome their reluctance to vary from traditional designs, which was found to be a significant or major barrier by $49 \%$ of respondents. Interestingly and contrary to the findings of cultural barriers regarding concerns over micro- 
renewables’ reliability and installation, the aesthetic of renewable technologies was not found to be much of a barrier, with only $10 \%$ of respondents stating that it is a major impediment. This was reiterated further during the interviews, as one informant put it: "renewable features were in some cases dominant façade elements and a symbol of modernity of a development”.

\subsection{Feasibility of Zero Carbon Homes}

When questioned on a realistic target year for zero carbon homes in England, respondents to the questionnaire opined that 2023 was more appropriate and realistic than the 2016 deadline. Interviewees were slightly divided over this matter with two of them believing that zero carbon homes are feasible by 2016, however, the overall consensus was that they would not be feasible across the board. Despite this, respondents commented that compulsory adoption and a step change in building practice were the most suitable ways of achieving the goal. The interviewees provided some more in-depth information in relation to the feasibility of zero carbon homes. It was recommended that a change in the government definition of zero carbon homes, which facilitated the use of Energy Service Companies (ESCo), would greatly reduce the overall cost of the CSH-compliant housing projects, and will ultimately increase the zero carbon homes feasibility. It was also mentioned that greater implementation of offsite construction in housing could reduce costs and help attain the required standards. One interviewee stated that the CSH "is no different to any other building regulation" and that "the industry will get on and achieve it if structured and integrated legislation is put in place”. Interviewees did stress, however, that if the government does make the CSH mandatory then they must do so in a holistic manner.

\section{Discussion}

Both the questionnaire respondents and interviewees raised some serious concerns that could jeopardise the government zero carbon agenda in the housing sector, unless a swift, all-embracing and above all realistic strategy is adopted and implemented across the supply chain. There was a call for rethinking the definition of 'zero carbon', as it is vague in its current format without clear and structured guidelines. This was correlated to house builders' unease to comply with the CSH's requirement to provide all energy from on-site renewable sources. It is believed that existing renewable technologies are unreliable and unfeasible to integrate in certain situations, which is supported by the findings of UKGBC (2008) [33]; Williams and Adair (2008) [21]; and Sullivan et al. (2006) [22]. House builders opined that the use of ESCos providing district renewable energy would be far more viable from a cost, maintenance, reliability, insurance and guarantee perspective and that this combined with the creation of effective legislation would increase the chance of achieving the government's zero carbon homes objective. 
Customer demand was seen by the surveyed house builders as an essential element in the widespread development of zero carbon homes, which confirms the findings of Darnton (2005) [11] and Carter (2006) [8]. It is, however, necessary for the government to act upon this growing demand and legislate to create a national market for zero carbon homes as highlighted by Vorsatz et al. (2007) [20] and reinforced by the findings of both the survey and interviews of this study.

The cost of sustainable measures were identified in studies by WWF (2004) [25], Williams and Adair (2007) [21] and Cato (2008) [26] as being prohibitive. The research revealed that house builders are concerned about commercial benefits and costs, which are still unknown, to build zero carbon homes. Consequently, some of them will be willing to absorb the costs in the case of the CSH becoming legislation unless it will be governed by a clear and comprehensive legal framework.

\section{Conclusions}

The aim of this paper was to capture the major house builders' views on the feasibility of zero carbon homes in the England by 2016. This has been achieved through a comprehensive literature review, and industry engagement via a questionnaire survey and semi-structured interviews. The study has found that although zero carbon homes are technically feasible in the long term, clear and concise action is required from both the government and the house building industry if they are to be achieved across the board by 2016 . The study has identified several areas requiring attention from the government, the most important of which is to prioritise their objectives for the house building industry and to legislate accordingly. This will involve tackling the zero carbon homes objective in a holistic manner, involving all stakeholders in the house building process and ensuring that planning authorities are not a hindrance. There is also a need to revise the zero carbon definition to facilitate the use of ESCos, as well as increase in customer awareness and demand. On the other hand, additional resources should be allocated by both government and industry to researching cost effective technological solutions to zero carbon homes. Optimising off-site construction techniques and processes could technically facilitate the implementation of the step changes required by the $\mathrm{CSH}$, which may be achieved with greater ease.

In light of the research findings, it has become clear that there is a need for a joined up and holistic approach to the zero carbon target, which should be guided by comprehensive and well rounded legislative measures. This should drive the implementation of the zero carbon homes agenda in a cohesive manner, ensuring that all stakeholders in the house building process, including material manufacturers, designers, local planning authorities, and house builders, are involved, committed, and above all adhere to the same guidelines with a clear and consistent roadmap. 


\section{Acknowledgements}

The authors wish to thank all the house building companies and individuals who kindly participated in the research. Their time and input in both the questionnaire survey and interviews is much appreciated. 


\section{References}

[1] DTI -Department of Trade and Industry, Energy White Paper: Our energy future -creating a low carbon economy, TSO, Norwich, 2003.

[2] Department of Energy and Climate Change, UK leads world with commitment to cut emissions by $80 \%$ by 2050, Department of Energy and Climate Change, London, October 2008. Available: Department of Energy and Climate Change [14/01/09].

[3] N. Stern, The economics of climate change, Cambridge University Press , 2006.

[4] DCLG - Department of Communities and Local Government, Lessons learnt: design for manufacture, the challenge to build a quality home for 60k, DCLG, London, June 2006.

[5] DCLG -Department of Communities and Local Government, The Callcutt review of housebuilding delivery, HMSO, London, 2007.

[6] DCLG -Department of Communities and Local Government, Code for Sustainable Homes: a step change in sustainable home building practice, HMSO, London, 2006.

[7] WWF -World Wide Fund, Building a sustainable future: UK home-builders progress in addressing sustainability, WWF-UK, Surrey, 2007.

[8] E. Carter, Making money from sustainable homes: a developers guide, CIOB Publications, Ascot, 2006.

[9] WWF - World Wide Fund, Investing in sustainability: progress and performance among the UK's listed house-builders, WWF-UK, Surrey, 2005.

[10] M. Keeping, D. E. Shiers, Sustainable property development: a real guide to real estate and the environment, Blackwell Publishing, Oxford, 2004.

[11] A. Darnton, Public Understanding of climate change, Futerra \& DEFRA, 2005.

[12] Sponge Sustainability Network, Eco chic or eco geek? The Desirability of Sustainable Homes, Sponge Sustainability Network, 2007.

[13] A. Dobson, Environmental citizenship: towards sustainable development, Sustainable Development 15 (2007) 276-285

[114] T. Lutzkendorf, D. Lorenz, Integrating Sustainability into Property Risk Assessments for Market Transformation, Building Research and Information 35 (6) (2007) 644-661.

[15] DCLG -Department of Communities and Local Government, Planning Policy Statement 1: delivering sustainable development, HMSO, London, 2005. 
[16] K. Adeyeye, M. Osmani, C. Brown, Energy conservation and building design: the environmental legislation push and pull factors, Structural Survey 25 (5) (2007) 375-390.

[17] B. Baiche, N. Walliman, R. Ogden, Compliance with building regulations in England and Wales, Structural Survey 24 (4) (2006) 279-299.

[18] CIOB -Chartered Institute Of Building, UK Policy handbook, CIOB, Ascot, 2007.

[19] S. Sayce, L. Ellison, P. Parnell, Understanding investment drivers for UK sustainable property, Building Research and Information 35 (6) (2007) 629-643.

[20] D. Vorsatz, S. Koeppel, S. Mirasgedis, Appraisal of policy instruments for reducing buildings’ CO2 emissions, Building Research and Information 35 (4) (2007) 458-477.

[21] K. Williams, C. Adair, What is stopping sustainable building in England? Barriers experienced by stakeholders in delivering sustainable development, Sustainable Development 15 (2007) 135-147.

[22] L. Sullivan, B. Mark, T. Parnell, Lessons for the Application of Renewable Energy Technologies in High Density Urban Locations, in: Proceedings of the 23rd Conference on Passive and Low Energy Architecture (PLEA2006), Geneva, 6-8th September 2006.

[23] P. Poyton, Perspectives on innovation: housing, Zedfactory, Surrey, 2003.

[24] R. Nelson, A. Peterhansi , B. Sampat, Why and how innovations get adopted: a tale of four models, Industrial and Corporate Change 13 (5) (2004) 679-699.

[25] WWF - World Wide Fund, Building towards sustainability: performance and progress among the UK’s leading housebuilders, WWF-UK, Surrey, 2004.

[26] I. Cato, Carbon zero homes UK style, Refocus 9 (2) (2008) 28-29.

[27] C. Sweett, Putting a price on sustainability, BRE Press, Watford, 2005.

[28] Faber Maunsell, Supporting and delivering zero carbon development in the South West, South West Regional Assembly and Taunton Dean Borough Council, 2007.

[29] BRE -Building Research Establishment, Reducing carbon emissions from the UK housing stock, BRE Press, Watford, 2005.

[30] P. F. G Banfill, A. D. Peacock, Energy Efficient New Housing - The UK Reaches for Sustainability, Building Research \& Information 35 (4) (2007) 426-436.

[31] J. Gusdorf, A. Parekh, Energy Efficiency and Indoor Air Quality in R-2000 and Conventional New Houses in Canada, ACEEE Summer Study on Energy Efficiency in Buildings 1 (2000) 1.101-1.112. 
[32] G. Hodgson,An introduction to Passivhaus: A guide for UK application, BRE INFORMATION PAPER IP (12) 2008.

[33] UKGBC -UK Green Building Council, The Definition of Zero Carbon, Zero Carbon Task Group Report, UKGBC, London, 2008. 